\title{
Synovial Procollagenase Activation by Human Mast Cell Tryptase Dependence upon Matrix Metalloproteinase 3 Activation
}

\author{
Barry L. Gruber," Mary J. Marchese, ${ }^{\star}$ Ko Suzuki, ${ }^{\ddagger}$ Lawrence B. Schwartz, ${ }^{5}$ Yasunori Okada," \\ Hideaki Nagase, ${ }^{\ddagger}$ and Nungavaram S. Ramamurthy" \\ *Division of Allergy, Rheumatology and Clinical Immunology, Veterans Administration, Northport, New York 11768, and \\ State University of New York at Stony Brook, Stony Brook, New York 11794-8161; ${ }^{\ddagger}$ Department of Biochemistry and Molecular \\ Biology, University of Kansas Medical Center, Kansas City, Kansas 66103; ${ }^{\S}$ Division of Rheumatology, Allergy, and Immunology, \\ Medical College of Virginia, Richmond, Virginia; "Department of Pathology, School of Medicine, Kanazawa University, \\ Kanazawa, Ishikawa-ken, Japan 920; 'Department of Oral Biology, School of Dental Medicine,
}

SUNY at Stony Brook, Stony Brook, New York 11794

\begin{abstract}
Mast cells have been implicated in the pathogenesis of the matrix degradation observed in the cartilaginous and osseous structures of the rheumatoid joint. We previously reported that human mast cell tryptase, a 134-kD granule-associated neutral protease, is present in rheumatoid synovium and can activate collagenase in crude culture medium in vitro. The present study attempts to depict the precise mechanism of this activation. To express full activation of latent collagenase, matrix metalloproteinase 3 (MMP-3) or stromelysin, can be activated by tryptase in a time and dose-dependent manner. Tryptase was not capable of generating active collagenase in the crude media from cultured rheumatoid synoviocytes depleted of proMMP-3 by immunoadsorption. In addition, the function of the tissue inhibitor of metalloproteinases (TIMP) was not altered by tryptase, and SDS-PAGE analysis revealed no degradation of TIMP by tryptase. The tryptase dependent activation of synoviocyte procollagenase thereby appears to be entirely dependent upon its ability to activate proMMP-3.
\end{abstract}

\section{Introduction}

Recent evidence suggests that a family of latent metalloproteinases may be elaborated by synovial adherent cells and, collectively these enzymes have the ability to degrade all the components of human extracellular matrix (1-6). The activation of latent collagenase (MMP-1 ${ }^{1}$ likely involves an enzymatic cascade that is dependent upon activation of the zymogen of MMP-3 (proMMP-3), which in turn, activates latent collagenase $(7,13)$. Once activated, MMP-3 additionally can degrade proteoglycans, fibronectin, laminin, type IV and type IX collagen, and gelatin $(1,4,5)$. The activation of proMMP-3 is therefore an important step in the initiation of matrix degra-

Address reprint requests to Dr. Gruber, Division of Allergy, Rhuematology, and Clinical Immunology, SUNY at Stony Brook, Stony Brook, NY 11794-8161. 1989.

Received for publication 15 May 1989 and in revised form 5 July

1. Abbreviations used in this paper: APMA, aminophenyl mercuric acetate; CM, conditioned media; DFP, diisopropylfluorophosphate; MMP-3, matrix metalloproteinase 3; proMMP-3, zymogen activation of MMP-3; TAME, tosyl-L-arginine methyl ester; TIMP, tissue inhibitor metalloproteinase.

The Journal of Clinical Investigation, Inc.

Volume 84, November 1989, 1657-1662 dation, and is likely the rate limiting step in collagenolysis (7, 13).

In vitro activation of proMMP-3 is attained with the addition of trypsin-like proteases or organomercurials $(4,7,14)$, but the activator in situ is unknown. Since mast cells accumulate in rheumatoid synovium and appear to be particularly prevalent near sites of cartilage erosion (15), we tested the hypothesis that these cells secreted a protease capable of initiating the collagenolytic process. Tryptase is a $134-\mathrm{kD}$ neutral protease selectively synthesized by mast cells (and in trace amounts by basophils) and comprising $>25 \%$ of the dry weight of these cells $(16,17)$. We and others have been unable to detect any specific matrix substance that is susceptible to degradation directly by tryptase $(18) .^{2}$ However, we previously reported that tryptase, when added to synoviocyte conditioned culture media, generated active collagenase (19). The precise pathway through which this activation proceeded was not elucidated. In this study we utilized purified reagents and specific antisera to more precisely define the mechanism of procollagenase activation to further explore the potential role of mast cells in matrix degradation.

\section{Methods}

Materials. Bacterial collagenase (Clostridia type II), hyaluronidase, trypsin, deoxyribonuclease, transferrin (human), diisopropylfluorophosphate (DFP), and soybean trypsin inhibitor were purchased from Sigma Chemical Co. (St. Louis, MO) and heparin from Gibco Laboratories (Grand Island, NY). Tryptase was purified to apparent homogeneity from dispersed human lung mast cells as described previously (17). Heparin $(10 \mu \mathrm{g} / \mathrm{ml})$ was added to all assays in which tryptase was used (19). ProMMP-3 was purified from human rheumatoid synovial cells stimulated by rabbit macrophage conditioned culture medium as described previously (13). Briefly, this involved applying $\sim 40 \mathrm{ml}$ of culture media to an affinity column of monospecific sheep anti-(human MMP-3) IgG coupled to Affi-Gel 10 (Bio-Rad) and eluting with $6 \mathrm{M}$ urea in $50 \mathrm{mM}$ Tris- $\mathrm{HCl}, \mathrm{pH}$ 7.5. The culture media in the effluent contained no detectable proMMP-3 activity, even after 4-aminophenylmercuric acetate (APMA). This was further confirmed by immunoblotting analysis. The culture medium depleted from proMMP-3 was stored at $-20^{\circ} \mathrm{C}$ for use in certain experiments.

Synovial latent collagenase was studied in both crude and partially purified forms after release into media by stimulated rheumatoid synoviocytes (19). Briefly, rheumatoid synovial tissue, obtained at the time of open surgical procedures, was minced and enzymatically digested before culture in Dulbecco's minimal essential media, penicillin, and streptomycin (in 5\% $\mathrm{CO}_{2}$ ). At confluency, either recombinant IL-1 (2-4 U/ml; Collaborative Research, Lexington, MA) or rabbit macrophage-conditioned medium is added for $12 \mathrm{~h}$ before harvesting

2. Gruber, B. L., N. M. Schecter, S. E. Carsons, J. Wolfe, and L. B. Schwartz. Manuscript submitted for publication. 
the media. Further purification of this media was performed as described previously $(20,21)$. Recombinant tissue inhibitor of metalloproteinase ( $r$-TIMP) was kindly provided by Dr. David Carmichael (Synergen, Boulder, CO).

Enzyme assays. Tryptase was assayed by its ability to cleave tosylL-arginine methyl ester (TAME) with resultant absorbance at $247 \mathrm{~nm}$, and further confirmed using an enzyme immunoassay, previously described (22). The enzymatic activity was not affected by soybean trypsin inhibitor. MMP-3 activity was measured using reduced, $\left[{ }^{3} \mathrm{H}\right]$ carboxymethylated transferrin $\left(\left[{ }^{3} \mathrm{H}\right] \mathrm{Cm}-\mathrm{Tf}\right)$ in $50 \mathrm{mM}$ Tris- $\mathrm{HCl}$, as described $(1,13,14) .1 \mathrm{U}$ of MMP-3 degraded $1 \mu \mathrm{g}$ of $\left[{ }^{3} \mathrm{H}\right] \mathrm{Cm}$-Tf per min at $37^{\circ} \mathrm{C}$. Collagenase activity was determined using $\left[{ }^{14} \mathrm{C}\right]$ acetylated type I collagen $(3 \mathrm{mg} / \mathrm{ml})$ isolated from guinea pig skin as a substrate (23). $1 \mathrm{U}$ of collagenolytic activity digested $1 \mu \mathrm{g}$ of collagen at $37^{\circ} \mathrm{C}$ per min.

Gel electrophoresis and immunoblots. SDS/PAGE (10\% total acrylamide) was performed under reducing conditions (20 mM DTT) using standard techniques and the proteins stained with Coomassie brilliant blue R-250 (24). To analyze the molecular weight changes of proMMP-3 upon tryptase treatment, the samples were applied to one dimensional electrophoresis, and the proteins were electro-transferred (25) overnight to nitrocellulose paper (Hoefer Scientific Instruments, San Francisco, CA), followed by a $2-h$ incubation with sheep antihuman MMP-3 at a dilution of 1:2,000. Bound antibodies were detected, by complexing with alkaline-phosphatase conjugated rabbit anti-sheep antibody at 1:500 dilution (Kirkegarrd-Perry, Gaithersburg, $\mathrm{MD}$ ), and visualizing with the substrate nitroblue tetrazolium, as described by Blake et al. (26).

Inhibition studies. To study the effects of tryptase on the metalloproteinase-TIMP complex, either partially purified synovial procollagenase activated with APMA $\left(1.5 \mathrm{mM}\right.$ at $24^{\circ} \mathrm{C}$ for $\left.30 \mathrm{~min}\right)$ or purified MMP-3 was incubated with increasing amounts of TIMP. After a

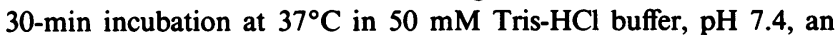
aliquot was removed and treated with tryptase at varying concentrations. The activity of collagenase or MMP-3 was then determined. In separate experiments, TIMP was initially treated with tryptase (1.0 $\mu \mathrm{g} / \mathrm{ml}$ at $37^{\circ} \mathrm{C}$ for $30 \mathrm{~min}$ ) and then added to the media containing APMA-activated collagenase or MMP-3 to determine whether the inhibitory capacity of TIMP was altered after tryptase treatment.

\section{Results}

Activation of proMMP-3. Purified proMMP-3 was activated by tryptase in a concentration-dependent fashion after $30 \mathrm{~min}$ at $37^{\circ} \mathrm{C}$. The maximal activity of MMP-3 was accomplished with $20 \mathrm{nM}$ tryptase $(27 \mu \mathrm{g} / \mathrm{ml})$, comparable to that seen with 35 $\mathrm{nM}(1 \mu \mathrm{g} / \mathrm{ml})$ of a known activator $\alpha$-chymotrypsin (Fig. 1). The activation process was terminated by the addition of $25 \mathrm{M}$ excess DFP. Tryptase was capable of activating proMMP-3 to $100 \%$ of its enzymatic activity, as determined by subsequent

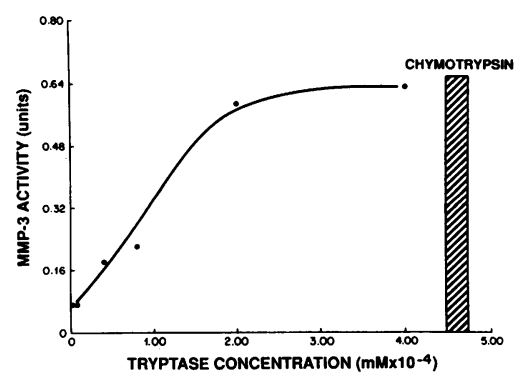

Figure 1. Activation of proMMP-3 by tryptase. ProMMP-3 was incubated with varying amounts of tryptase for $30 \mathrm{~min}$ at $37^{\circ} \mathrm{C}$ and MMP-3 activity was measured against $\left[{ }^{3} \mathrm{H}\right] \mathrm{Cm}-\mathrm{Tf}$. The full activation was attained by a standard amount of $\alpha$-chymotrypsin (35 nM) (see reference 9). treatment with APMA for $12 \mathrm{~h}$. Tryptase alone had no degradative activity when incubated directly with the MMP-3 substrate, $\left[{ }^{3} \mathrm{H}\right] \mathrm{Cm}-\mathrm{Tf}$.

Western blot-analysis of tryptase-activated MMP-3. Purified proMMP-3 and the tryptase-activated MMP-3 were subjected to SDS-PAGE under reducing conditions and analyzed by immunoblotting using monospecific antisera to MMP-3. As shown in Fig. 2, a sequential processing of proMMP-3 by $25 \mathrm{nM}$ tryptase $(3.3 \mu \mathrm{g} / \mathrm{ml})$ occurred over $18 \mathrm{~h}$. An intermediate proMMP-3 product of $49 \mathrm{kD}$ was seen after a 30 -min incubation with tryptase, which was then converted to a $45-\mathrm{kD}$ species after $120 \mathrm{~min}$. This molecular weight conversion is complete after an 18-h incubation. Maximal activity of MMP-3 is observed after $2 \mathrm{~h}$ and is comparable to that attained with $\alpha$-chymotrypsin and APMA. No diminution of MMP-3 activity was observed after $18 \mathrm{~h}$.

Activation of latent collagenase. Crude media containing latent collagenase was treated with trypsin, APMA, and tryptase. DFP was added to inactivate tryptase and trypsin after activation of the media and before the exposure to the collagenase assay. As shown in Table I all of these treatments of the crude culture medium activated procollagenase. However, after exhaustive immunoadsorption of the media to remove proMMP-3 (CM-proMMP-3), the tryptase was incapable of activating the crude media even after $60 \mathrm{~min}$ (Table I). Consistent with previous experiments, tryptase itself showed negligible collagenase activity directly (data not shown). Hence, tryptase activation of synovial procollagenase appears dependent upon the presence of MMP-3.

This observation is further confirmed by examining the digestion of collagen with SDS-PAGE, using tryptase-activated crude conditioned media (CM) before and after immunoadsorption of proMMP-3. As shown in Fig. 3, interstitial collagen is degraded at room temperature after $14 \mathrm{~h}$ by synoviocyte

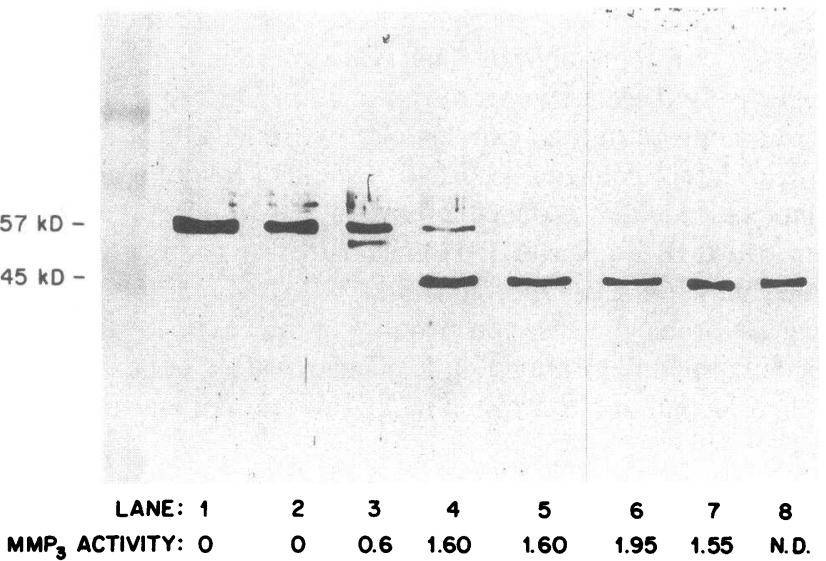

Figure 2. Western blot analysis of activation of proMMP-3 and molecular weight changes after incubation with tryptase at $22^{\circ} \mathrm{C}$ for various times as compared to $\alpha$-chymotrypsin and APMA. Lane 1 proMMP-3; lanes 2-5, proMMP-3 treated with tryptase (25 $\mathrm{nM}$ ) for $1 \mathrm{~min}, 30 \mathrm{~min}, 120 \mathrm{~min}$, and $18 \mathrm{~h}$; lane 6, proMMP-3 treated with $\alpha$-chymotrypsin ( $35 \mathrm{nM}$ ) for $30 \mathrm{~min}$ (above reactions stopped with DFP), lanes 7 and 8, proMMP-3 treated with APMA (1.5 mM) for 4 $\mathrm{h}$ and $18 \mathrm{~h}$, respectively. The samples were subjected to SDS/PAGE ( $10 \%$ total acrylamide) with reduction before nitrocellulose transfer and visualization as described in Methods. Also shown is the MMP-3 enzymatic activity at each time point as assessed by its ability to cleave $\left[{ }^{3} \mathrm{H}\right] \mathrm{Cm}-\mathrm{Tf}$. 
Table I. Activation of Procollagenase in Crude Culture of Rheumatoid Synovial Cells

\begin{tabular}{|c|c|c|c|c|}
\hline & \multicolumn{2}{|r|}{$30 \mathrm{~min}$} & \multicolumn{2}{|r|}{$1 \mathrm{~h}$} \\
\hline & & (\% Activation) & & (\% Activation) \\
\hline & $U / m l$ & & $U / m l$ & \\
\hline \multicolumn{5}{|l|}{ Crude media (CM) } \\
\hline+ TNC & 0.9 & 4.9 & 0.9 & 4.9 \\
\hline + APMA (1.5 mM) & 12.3 & 67.2 & 18.3 & 100.0 \\
\hline+ Tryptase $(10 \mu \mathrm{g} / \mathrm{ml})$ & 7.1 & 38.8 & 7.4 & 40.4 \\
\hline+ Trypsin $(10 \mu \mathrm{g} / \mathrm{ml})$ & 21.3 & 116.4 & - & - \\
\hline \multicolumn{5}{|l|}{ (CM-ProMMP-3) } \\
\hline$+\mathrm{TNC}$ & 1.6 & 8.7 & 3.4 & 18.6 \\
\hline + APMA & 5.1 & 27.9 & 3.7 & 20.2 \\
\hline + Tryptase & 0.0 & 0.0 & 0.0 & 0.0 \\
\hline
\end{tabular}

* TNC, Buffer; $50 \mathrm{mM}$ Tris- $\mathrm{HCl}, \mathrm{pH} 7.5 / 10 \mathrm{mM} \mathrm{CaCl}_{2} / 0.15 \mathrm{M}$ $\mathrm{NaCl} / 0.02 \% \mathrm{NaN}_{3}$.

Full activation of procollagenase was taken from the APMA-treatment of the crude culture medium at $37^{\circ} \mathrm{C}$ for $1 \mathrm{~h}$.

culture media, which was activated by either APMA or tryptase only if proMMP-3 was present in the media.

Effect of tryptase on tissue inhibitor. The possibility that tryptase might interact with the enzyme-inhibitor complex to yield free enzyme and inactivate inhibitor was investigated. Recombinant TIMP (10 $\mu \mathrm{M})$ was allowed to incubate with synoviocyte crude media which was previously activated by trypsin $(10 \mu \mathrm{g} / \mathrm{ml}$ for $30 \mathrm{~min})$. As shown in Table II, tryptase (40 $\mathrm{nM}$ ) had no functional effect on the inactive collagenaseTIMP complex after $30 \mathrm{~min}$ incubation. Furthermore, if tryptase ( $40 \mathrm{nM})$ was allowed to incubate with TIMP initially for $30 \mathrm{~min}$ and the inhibitor was subsequently added to active collagenase, no significant loss of inhibitory activity was ob-

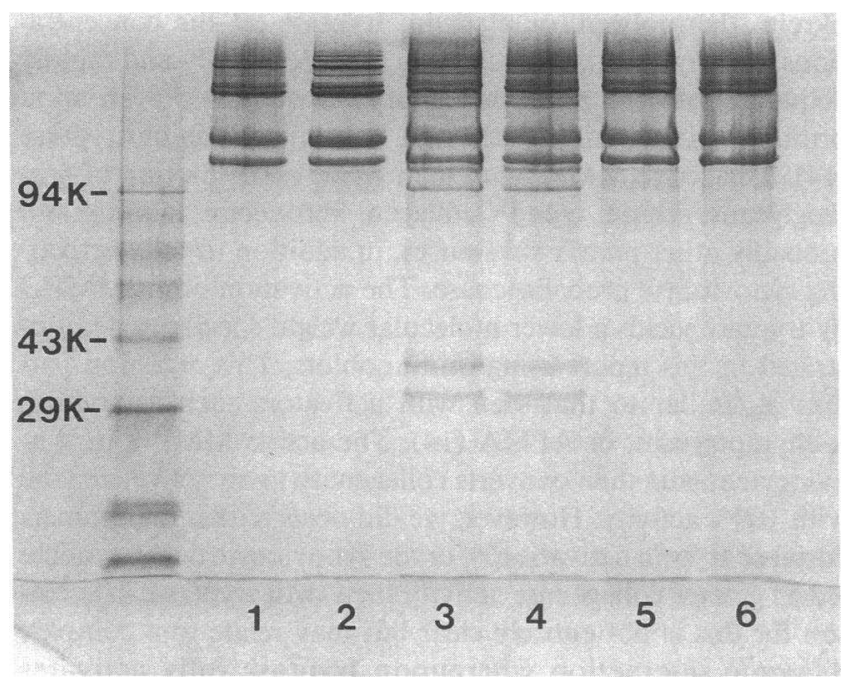

Figure 3. Degradation of purified collagen by synoviocyte CM. After incubation at $23^{\circ} \mathrm{C}$ for $14 \mathrm{~h}$ the products were subjected to SDSPAGE (7.5\% acrylamide), stained with Coomassie blue. The collagen was exposed to lane 1, buffer; lane 2, CM; lane 3, CM + APMA (1.5 $\mathrm{mM}$ ); lane 4, CM + tryptase; lane 5, CM depleted of proMMP-3; and lane $6, C M$ depleted of proMMP-3 + tryptase $(10 \mu \mathrm{g} / \mathrm{ml})$.
Table II. The Effect of Tryptase on Inhibition of Collagenase by TIMP

\begin{tabular}{lc}
\hline & Units of activity \\
\hline Crude media (CM) & 15.6 \\
CM + APMA & 108.4 \\
CM + Trypsin (Tn) & 155.7 \\
{$[C M+$ Tn] + TIMP } & 0 \\
{$[C M+T n]+[$ TIMP + tryptase $]$} & 0 \\
$\{[C M+$ Tn] + TIMP $\}+$ tryptase & 0
\end{tabular}

Collagenase activity determined before and after various treatments. Activation of conditioned crude media (CM) is demonstrated with APMA $(1.5 \mathrm{mM})$ and trypsin $(10 \mu \mathrm{g} / \mathrm{ml})$. The latter is inhibited after incubation with TIMP $(10 \mu \mathrm{M})$. Treatment of TIMP $(10 \mu \mathrm{M})$ with tryptase $(40 \mathrm{nM})$, subsequently added to activated collagenase, is shown. Lastly, activated collagenase is treated with TIMP $(10 \mu \mathrm{M})$ and then subsequently exposed to tryptase $(40 \mathrm{nM})$.

served (Table II). To investigate the possibility that TIMP exposed to tryptase might result in a partial loss of inhibitory capacity not revealed when TIMP was tested in excess concentrations relative to collagenase, decreasing amounts of TIMP were examined before and after tryptase exposure. As shown in Fig. 4, no significant effect was seen after TIMP was exposed to tryptase in its ability to inhibit collagenase regardless of the stoichiometric relationship between TIMP and collagenase.

Varying concentrations of native TIMP $(0.36-360 \mathrm{nM})$ added to active MMP-3 $\left(10^{-1}-10^{3} \mathrm{nM}\right)$ yielded the expected concentration-related inhibition (Fig. 5). Even when TIMP was treated with tryptase ( $60 \mathrm{nM}$ for $1 \mathrm{~h}$ ) stabilized with heparin or heparin alone, a similar stoichiometric inhibition for MMP-3 was obtained (Fig. 5), indicating that tryptase (or heparin) was ineffective in inactivating TIMP. Lastly, TIMP was

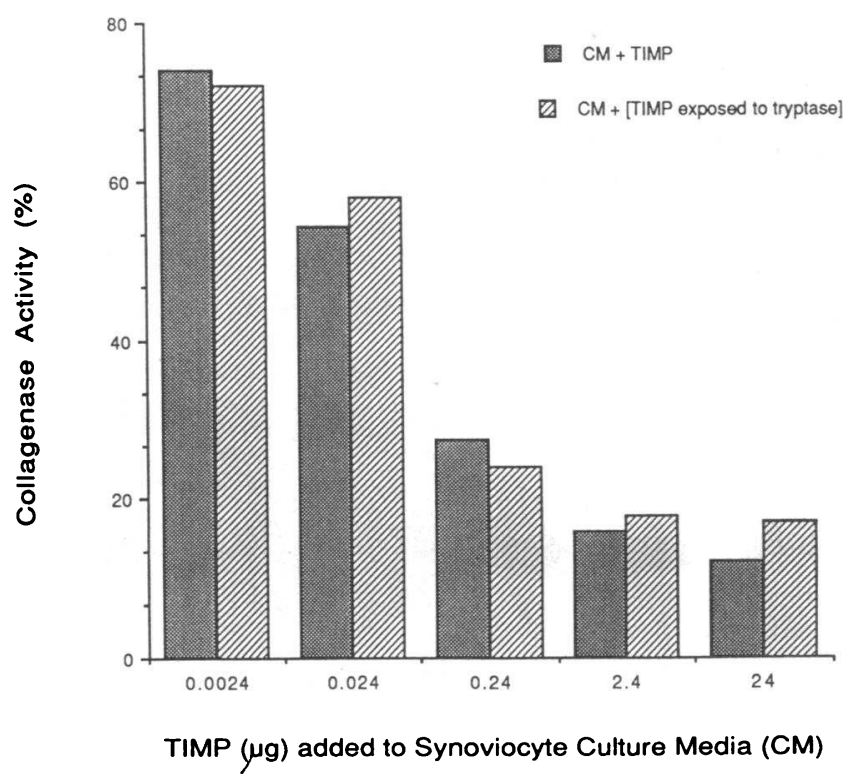

Figure 4. Effect of tryptase incubation with TIMP on the ability of TIMP to inhibit collagenase in crude CM. TIMP was exposed to tryptase for $60 \mathrm{~min}$ at $37^{\circ} \mathrm{C}$, and then various concentrations were added to crude $\mathrm{CM}$ and residual collagenase activity determined. The amount of collagenase activity in the absence of TIMP was defined as $100 \%$ activity. 


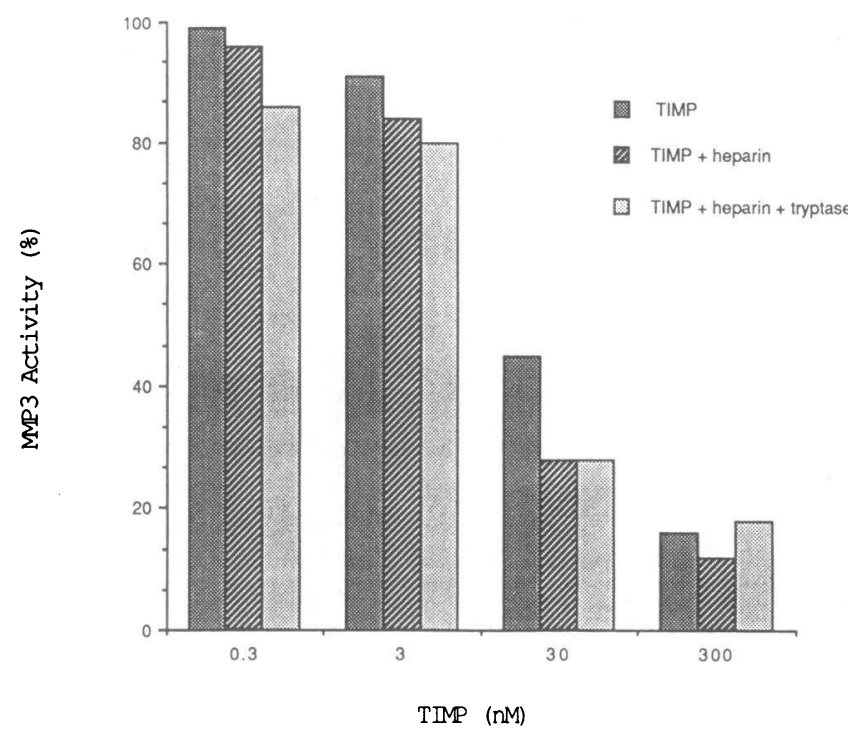

Figure 5. Effect of tryptase on TIMP activity against MMP-3. TIMP was incubated with buffer, heparin $(10 \mu \mathrm{g} / \mathrm{ml})$, or tryptase (with heparin) at $37^{\circ} \mathrm{C}$ for $1 \mathrm{~h}$. Various concentrations of TIMP were then added to $1 \mu \mathrm{M}$ of active MMP-3 and the degree of residual enzyme activity determined. The amount of MMP-3 activity in the absence of TIMP was taken as $100 \%$ activity.

analyzed by SDS-PAGE under reducing conditions $(20 \mathrm{mM}$ DTT) before and after treatment with tryptase $(2.5 \mu \mathrm{g} / \mathrm{ml})$. No change could be detected after $\gamma$ tryptase treatment (Fig. 6). Therefore, tryptase had no measurable effect on the metalloproteinase inhibitor.

\section{Discussion}

Impaired extracellular regulation of metalloproteinases released by specialized synovial cells is central in the develop-

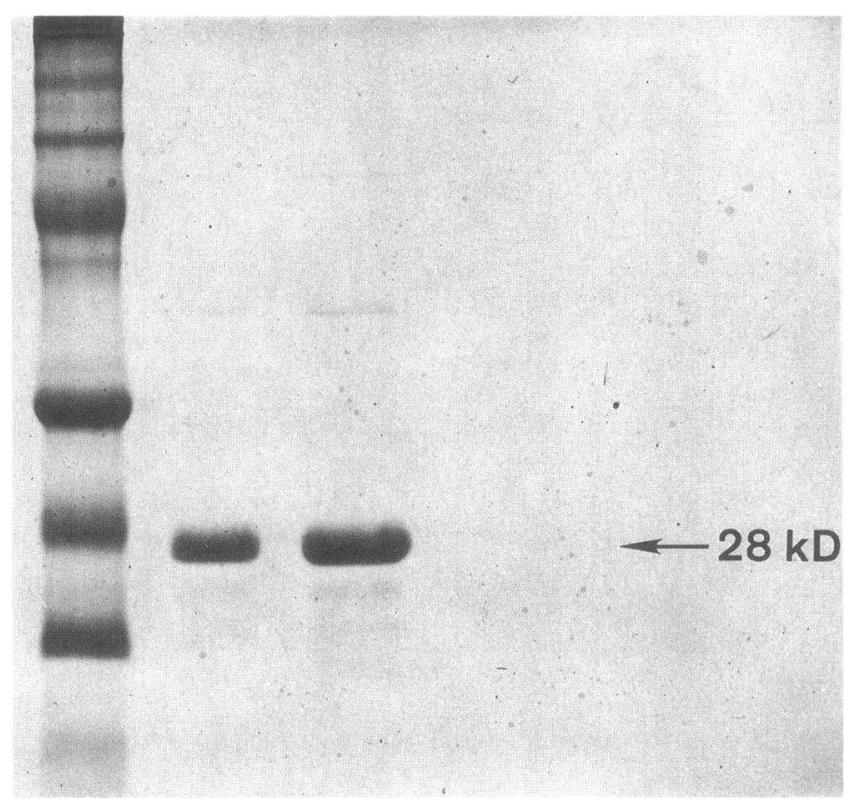

Figure 6. SDS-PAGE (15\% acrylamide) analysis of recombinant TIMP treated with tryptase. The products were visualized with Coomassie brilliant blue. Lane 1 , molecular weight standards; lane 2 , native TIMP; and lane 3, TIMP after $30 \mathrm{~min}$ digestion at $37^{\circ} \mathrm{C}$ with tryptase $(2.5 \mu \mathrm{g} / \mathrm{ml})$. ment of premature articular breakdown in rheumatoid arthritis $(27,28)$. It appears that these latent proteinases are secreted in excess after enhanced cellular transcription and translation, under the influence of specific cytokines or other endogenous activators (29-31). The proenzymes are then activated extracellularly and may either proceed to degrade the matrix or else complex with tissue inhibitors. In vitro, this activation occurs spontaneously or by interacting with neutral serine proteases or organomercurials (32). The precise manner in which this occurs in situ is unknown. Plasma kallikrein has been proposed as a major activator in synovial fluid (33), but documentation of its presence at the site of cartilage erosion is lacking. However, mast cells have been noted to accumulate in clusters at the cartilage-pannus junction (15). Furthermore, tryptase, the major neutral protease of human mast cells, can be demonstrated by immunoperoxidase techniques in rheumatoid synovium $(19,34)$. Previously, we reported that synovial mast cells in vitro can be induced to release tryptase and activate latent collagenase present in crude culture media (19).

The mechanism in which tryptase leads to an active form of collagenase is explored in this report. The activation of procollagenase occurs after cellular release and recent evidence suggests that full activation likely involves an intermediary "proactivator" (7-13). It has been proposed that this proactivator has in itself a broad spectra of metal-dependent matrix degrading activities and represents a member of a family of metalloproteinases, termed MMP-3 or stromelysin $(4-6,35)$. Rheumatoid synoviocytes release a latent form of MMP-3 in culture and its properties after purification have been described $(1,4,7)$. Furthermore, depleting rheumatoid synoviocyte media of MMP-3 by immunoadsorption followed by activation by trypsin or APMA reduces the collagenolytic activity by over $80-90 \%(12,13)$.

Our results, which indicate that prompt activation of purified proMMP-3 can result from incubation with physiologic concentrations of mast cell tryptase, adds to the list of serine esterases that can lead to an active MMP-3 moiety. However, in comparison to other endopeptidases such as trypsin, kallikrein, thermolysin, or plasmin, tryptase (at the concentrations employed in this study) was capable of fully and rapidly activating MMP-3 and this activity was sustained even upon prolonged incubation with high concentrations of tryptase (14). The active MMP-3 can then result in dissolution of proteoglycans, gelatin, type IV collagen, fibronectin, laminin and probably other matrix substances, in addition to fully activating synoviocyte procollagenase. The activation of proMMP-3 by tryptase yields a lower molecular weight species as demonstrated in this report using immunoblots. This digestion pattern is similar to that seen with activators such as trypsin, $\alpha$-chymotrypsin, or APMA (14). The active MMP-3 in synoviocyte media then converts collagenase to an active enzyme with $100 \%$ activity. However, we did observe that organomercurial or trypsin activation of crude synoviocyte culture media led to greater collagenase activity then with tryptase. The reason for this is not entirely clear but may relate to a complex dynamic interaction whereupon tryptase fully activates proMMP-3 but simultaneously degrades collagenase in a manner to reduce its maximal activity. ${ }^{3}$

3. Gruber, B. L., M. J. Marchese, H. G. Welgus, and L. B. Schwartz. Manuscript submitted for publication. 
The other possible mechanism leading to an active collagenase species is to interfere with the ability of the tissue inhibitor to counteract the activated enzyme following exposure to certain serine proteinases, as reported previously (36). This might occur by either degrading the inhibitor upon exposure to tryptase or by dissociating the enzyme-inhibitor complex to yield free enzyme. Both of these possibilities were tested using recombinant TIMP incubated with tryptase before and after exposure to active MMP-3 or active collagenase in crude media. Under the experimental conditions employed, no significant effect of tryptase was observed.

The contribution of mast cell products in altering connective tissue metabolism remains unknown at present, but is likely to be considerable. Mast cells are prevalent in connective tissues and accumulate in chronic inflammatory conditions marked by abnormal homeostasis of connective tissue elements. This includes not only synovitis, which results in cartilage dissolution, but also in chronic periodontitis, in invasive carcinoma, and at sites of collagen excess in a number of pathologic settings (37-46). Whether the cells in the latter setting are promoting scar formation or, playing a frustrated part in attempting dissolution, is unclear. Nonetheless, human mast cells are unique in their abundance of the neutral protease, tryptase. Plasma and tissue protease inhibitors appear ineffective in regulating this enzyme $(16,17)$. Consequently, tryptase complexed with heparin may act locally in an uninhibited fashion. Thus mast cells, which have been observed near sites of cartilage erosion, may contribute to matrix degradation during the development of the rheumatoid pannus. The biochemical mechanism involves a cascade of several metalloproteinases; tryptase may serve a critical role initiating this pathological process.

\section{Acknowledgments}

We thank Ms. Myra Ward for her secretarial assistance and Ms. Rikako Suzuki for her competent technical assistance.

This work was supported by a Veteran's Administration Merit grant, National Institutes of Health grant AR-39189 and a grant from Speas Foundation, National Institutes of Health grant AI-20487 and DEO3987.

\section{References}

1. Okada, Y., H. Nagase, and E. D. Harris. 1986. A metalloproteinase from human rheumatoid synovial fibroblasts that digests connective tissue matrix components. J. Biol. Chem. 261:14245-14255.

2. Harris, E. D., H. G. Welgus, and S. M. Krane. 1984. Regulation of the mammalian collagenases. Collagen Rel. Res. 4:493-512.

3. Sellers, A., J. J. Reynolds, and M. C. Meikle. 1978. Neutral metallo-proteinases of rabbit bone. Separation in latent forms of distinct enzymes that when activated degrade collagen, gelatin and proteoglycans. Biochem. J. 171:493-496.

4. Chin, J. R., G. Murphy, and Z. Werb. 1985. Stromelysin, a connective tissue-degrading metalloendopeptidase secreted by stimulated rabbit synovial fibroblasts in parallel with collagenase. J. Biol. Chem. 260:12307-12376.

5. Okada, Y., H. Konomi, T. Yada, K. Kimata, and H. Nagase. 1989. Degradation of type IX collagen by matrix metalloproteinase 3 (stromelysin) from human rheumatoid synovial cells. FEBS (Fed. Eur. Biochem. Soc.) Lett. 244:473-476.

6. Murphy, G., G. G. McAlpine, C. T. Poll, and J. J. Reynolds.
1985. Purification and characterization of a bone metalloproteinase that degrades gelatin and type IV and V collagen. Biochim. Biophys. Acta. 831:49-58.

7. Vater, C. A., H. Nagase, and E. D. Harris, Jr. 1983. Purification of an endogenous activator of procollagenase from rabbit synovial fibroblast culture medium. J. Biol. Chem. 258:9374-9382.

8. Vaes, G. 1972. Multiple steps in the activation of the inactive precursor of bone collagenase by trypsin. FEBS (Fed. Eur. Biochem. Soc.) Lett. 28:198-200.

9. Eeckhout, Y., and G. Vaes. 1977. Further studies of the activation of procollagenase, the latent precursor of bone collagenase. Biochem. J. 166:21-31.

10. Ishibashi, M., A. Ito, K. Sakyo, and Y. Mori. 1987. Procollagenase activator produced by rabbit uterine cervical fibroblasts. Biochem. J. 241:527-534.

11. Treadwell, B. V., J. Neidel, M. Pavia, C. A. Towle, M. E. Trice, and H. J. Mankin. 1986. Purification and characterizations of collagenase activator protein synthesized by articular cartilage. Arch. Biochem. Biophys. 251:715-723.

12. Murphy, G., M. I. Crockett, P. E. Stephens, B. J. Smith, and A. J. P. Dorherty. 1987. Stromelysin is an activator of procollagenase. A study with natural and recombinant enzymes. Biochem. $J$. 248:265-268.

13. Ito A., and H. Nagase. 1988. Evidence that human rheumatoid synovial matrix metalloproteinase 3 is an endogenous activator of procollagenase. Arch. Biochem. Biophys. 267:211-216.

14. Okada, Y., E. D. Harris, Jr., and H. Nagase. 1988. The precursor of metalloendopeptidase from human rheumatoid synovial fibroblasts. Purification and mechanisms of activation by endopeptidase and 4-aminophenylmercuric acetate. Biochem. J. 254:731-741.

15. Bromley, M., W. D. Fischer, and D. E. Woolley. 1984. Mast cells at site of cartilage erosion in the rheumatoid joint. Ann. Rheum. Dis. 43:76-79.

16. Schwartz, L. B., R. A. Lewis, D. Seldin, and K. F. Austen. 1981. Acids hydrolases and tryptase from secretory granules of dispersed human lung mast cells. J. Immunol. 126:1290-1296.

17. Schwartz, L. B., R. A. Lewis, and K. F. Austen. 1981. Tryptase from humans pulmonary mast cells: purification and characterization. J. Biol. Chem. 256:11939-11942.

18. Johnson, D. H., and T. E. Cawston. 1985. Human lung mast cell tryptase fails to activate procollagenase or degrade proteoglycan. Biochem. Biophys. Res. Commun. 132:453-455.

19. Gruber, B. L., L. B. Schwartz, N. S. Ramamurthy, A. M. Irani, and M. J. Marchese. 1988. Activation of latent rheumatoid synovial collagenase by human mast cell tryptase. J. Immunol. 140:3936-3942.

20. Schwartz, L. B., and T. M. Bradford. 1986. Regulation of tryptase from human lung mast cells by heparin: stabilization of the active tetramer. J. Biol. Chem. 261:7372-7376.

21. Bejarano, P. A., M. E. Noelken, K. Suzuki, B. G. Hudson, and H. Nagase. 1988. Degradation of basement membranes by human matrix metalloproteinase 3 (stromelysin). Biochem. J. 256:413-419.

22. Wenzel, S., A. M. Irani, J. M. Sanders, T. R. Bradford, and L. B. Schwartz. 1986. Immunoassay of tryptase from human lung mast cells. J. Immunol. Methods. 86:139-142.

23. Cawston, T. E., and A. J. Barrett. 1979. A rapid and reproducible assay for collagenase using $\left[1-{ }^{14} \mathrm{C}\right]$ acetylated collagen. Anal. Biochem. 99:340-345.

24. Laemmli, U. K. 1970. Cleavage of structural proteins during the assembly of the head of bacteriophage T4. Nature (Lond.). 227:680-683.

25. Towbin, H., T. Staehelin, and J. Gordan. 1979. Electrophoretic transfer of proteins from polyacrylamide gels to nitrocellulose sheets: procedures and some applications. Proc. Natl. Acad. Sci. USA 76:4350-4354.

26. Blake, M. S., K. H. Johnston, G. J. Russell-Jones, and E. C. Gotschlich. 1984. A rapid, sensitive method for detection of alkalinephosphatase anti-antibody on Western blot. Anal. Biochem. 136:175179. 
27. Harris, E. D., Jr. 1976. Recent insights into the pathogenesis of the proliferative lesion in rheumatoid arthritis. Arthritis Rheum. 19:68-72.

28. Mainardi, C. L. 1987. The role of connective tissue degrading enzymes in human pathology. In Connective Tissue Disease. J. Uitto and A. J. Perejda, editors. Marcel Dekker, Inc., New York. 523-543.

29. Dayer, J. M., B. de Rochemonteix, B. Burrus, S. Demozuk, and C. A. Dinarello. 1986. Human recombinant interleukin-1 stimulates collagenase and $\mathrm{PGE}_{2}$ production by human synovial cells. J. Clin. Invest. 77:645-648.

30. Brinckerhoff, C. E., T. I. Mitchell, M. J. Karmilowicz, B. Kluve-Beckerman, and M. D. Benson. 1989. Autocrine induction of collagenase by serum amyloid A-like and $\beta_{2}$-microblobulin-like proteins. Science (Wash. DC). 243:655-657.

31. Werb, Z., C. L. Mainardi, C. A., Vater, and E. D. Harris, Jr. 1977. Endogenous activation of latent collagenase by rheumatoid synovial cells. Evidence for a role of plasminogen activator. $N$. Engl. J. Med. 296:1017-1023.

32. Cawston, T. E., E. Mercer, and J. A. Tyler. 1981. The activation of latent pig synovial collagenase. Biochim. Biophys. Acta. 657:73-83.

33. Nagase, H., T. E. Causton, M. DeSilva, and A. J. Barrett. 1982 Identification of plasma kallikrein as an activator of latent collagenase in rheumatoid synovial fluid. Biochim. Biophys. Acta. 702:133-142.

34. Irani, A. M., N. Golzar, G. Deblois, and B. L. Gruber. 1987. Distribution of mast cell subsets in rheumatoid arthritis and osteoarthritis synovia. Arthritis Rheum. 30:566. (Abstr.)

35. Murphy, G., H. Nagase, and C. E. Brinckerhoff. 1988. Relationship of procollagenase activator, stromelysin and matrix metalloproteinase 3. Collagen Rel. Res. 8:389-391.

36. Okada, S., Watanabe, I. Nakanishi, J. Kishi, T. Hayakawa, W. Watorek, J. Travis, and H. Nagase. 1988. Inactivation of tissue inhibitor metalloproteinases by neutrophil elastase and other serine proteinases. FEBS (Fed. Eur. Biochem. Soc.) Lett. 229:157-160.

37. Gruber, B., M. Poznansky, E. Boss, J. Partin, P. Gorevic, and
A. P. Kaplan. 1986. Characterization and functional studies of rheumatoid synovial mast cells: activation by secretagogues, anti-IgE and histamine-releasing lymphokine. Arthritis Rheum. 29:944-955.

38. Crisp, A. J., C. M. Chapman, S. E. Kirkham, A. C. Schiller, and S. M. Krane. 1984. Articular mastocytosis in rheumatoid arthritis. Arthritis Rheum. 27:845-855.

39. Godfrey, H. P., C. F. Illardi, W. Engber, and F. M. Graziano. 1984. Quantitation of human synovial mast cells in rheumatoid arthritis and other rheumatic diseases. Arthritis Rheum. 27:852-856.

40. Malone, D. G., R. C. Wilder, A. M. Saavedra-Delgado, and D. D. Metcalfe. 1987. Mast cell numbers in rheumatoid synovial tissues: correlation with quantitative measures of lymphocytic infiltration and modulation by anti-inflammatory therapy. Arthritis Rheum. 30:130-138.

41. Freemont, A. J., and J. Denton. 1985. Disease distribution of synovial fluid mast cells and cytophagocytic mononuclear cells and cytophagocytic mononuclear cells in inflammatory arthritis. Ann. Rheum. Dis. 44:312-315.

42. Jeffcoat, M. D., R. C. William, and H. G. Johnson. 1985. Treatment of periodontal disease in beagles with iodoxamide ethyl, an inhibitor of mast cell release. J. Periodont. Res. 20:532-541.

43. Dabbous, M. K., R. Walker, L. Haney, L. M. Carter, G. L. Nicolson, and D. E. Woolley. 1986. Mast cells and matrix degradation at sites of tumour invasion in rat mammary adenocarcinoma. $\mathrm{Br}$. $\mathrm{J}$. Cancer. 54:459-465.

44. Goto, T., D. Befus, R. L. Low, and J. Bienenstock. 1984. Mast cell heterogeneity and hyperplasia in bleomycin-induced pulmonary fibrosis in rats. Am. Rev. Respir. Dis. 130:797-802.

45. Hawkins, R. A., H. N. Claman, R. A. Clark, and J. C. Steigerwald. 1985. Increased dermal mast cell populations in progressive systemic sclerosis: a link in chronic fibrosis? Ann. Intern. Med. 102:182186.

46. Claman, H. N. 1985. Mast cells, T cells and abnormal fibrosis. Immunol. Today. 6:192-194. 